\title{
Letter to the Editor: Response
}

\author{
RICHARD B. JOHNSTON, JR.
}

Department of Pediatrics, National Jewish Hospital and Research Center/National Asthma Center and University of Colorado School of Medicine, Denver, Colorado, USA

Dr. Silverman denounces the intellectual separation, even distrust, that can exist between researcher and clinician, and I am in deepest sympathy with this point of view. Certainly, snobbery can never be justified nor should it be tolerated among those who share goals that are ultimately common. Unfortunately, the comments in the news report cited by Dr. Silverman were taken out of context, and Dr. Silverman has been led to interpret incorrectly their intent. The interested reader and Dr. Silverman might wish to consult the address, in which I define research in pediatrics as that "done by pediatricians in their laboratory or office," which would "not necessarily call for the use of pipets or animals"; and in which the introduction states that participating in research clearly is not required to become a complete pediatrician or persuasive educator (1).

The address does suggest, however, that one can graduate from medical school and complete a residency without really understanding that much of the status quo in medicine is inadequate and needs changing, that attaching a label to a patient by naming his disease is not the same as understanding the disease process, and that a sound history and physical examination continue to tell you more about the patient than do laboratory tests in most cases. Participating in research of substance, which could be clinical research (1) but which could absolutely never consist of "going through the motions of science," has helped many clinicians achieve a more critical, analytic view of what they practice. I agree with Dr. Silverman that knowledge gained through study of molecular and cellular events needs to be applied to the diagnosis and management of disease. It is my opinion that this particularly difficult task is most likely to be accomplished by physicians whose dissatisfaction with the status quo, critical viewpoint, and knowledge of basic mechanisms have been strengthened by participation in good research.

\section{REFERENCES AND NOTES}

1. Johnston, R. B., Jr.: The impact of research in pediatrics on the health of children. Pediatr. Res., 15: 1465 (1981).

\section{Letter to the Editor: Inapplicability of the Logarithmic Regression Equation for the Factorial Calculation of Total Body Iron in Preschool Children}

\author{
BENJAMIN CABALLERO, NOEL W. SOLOMONS, AND BENJAMIN TORÚN
}

Division of Human Nutrition and Biology, Institute of Nutrition of Central America and Panama, Guatemala City, Guatemala, Apartado 11-88

\begin{abstract}
The majority-99\%- of the iron in the body is contained in two compartments: (1) circulating iron (the iron in the hemoglobin or red blood cells) and (2) storage iron (the iron in ferritin and hemosiderin in hepatocytes, in reticuloendolium of bone marrow and spleen, and in the muscle tissue $(1,2)$. If sufficiently accurate and precise indirect indices of these iron pools were available, one could readily monitor the changes in total body iron balance without recourse to metabolic balance procedures or isotopic turnover studies. Data on hemoglobin concentrations and blood volume allow for the estimation of total circulating iron, and serum ferritin provides an index of storage iron (3-5). An "opportunistic" factorial approach to calculating total body iron has been applied recently to the estimation of iron absorption in infants in two publications in Pediatric Research $(6,7)$.

The exact relationship between a rise or fall in serum ferritin (SF) concentration and the gain or loss of storage iron is not established for all age groups. A relationship of $1 \mathrm{ng} / \mathrm{ml}$ of SF to each $8 \mathrm{mg} \mathrm{(3)}$ or $10 \mathrm{mg}$ (4) of storage iron has been suggested. Jacob et al. (8) have shown that SF levels fall more rapidly when iron reserves are abundant, and more gradually as they are
\end{abstract}

reduced, indicating a curvilinear response in an individual subject. Saarinen and Siimes (6) developed a regression equation relating the $\log 10$ of SF concentrations to the storage iron content per $\mathrm{kg}$ of body weight in a linear fashion $(y=0.0439 x+1.345)$ where $y$ is the $\log 10$ of serum ferritin concentration in $\mathrm{ng} / \mathrm{ml}$ and $\mathrm{x}$ is storage iron density in $\mathrm{mg} / \mathrm{kg}$. It was developed from data on newborns, infants, and adult men and women, but a general applicability is claimed for the equation. We encountered both practical and theoretical problems, however, in attempting to apply the factorial calculation of total body iron to preschool children using the Saarinen and Siimes equation.

If the published experimental data from which an estimate of true storage iron content of preschool children is examined, inconsistencies with the log-linear relationship become apparent. Widdowson and Dickerson (9) found the total body iron content of one $14-\mathrm{kg}$ child to be $896 \mathrm{mg}$. If we assume that $428 \mathrm{mg}$ of this iron content was in the circulating pool (see Appendix), then 468 $\mathrm{mg}$ of storage iron would have been present, representing $33 \mathrm{mg} /$ kg. Data for liver iron content for preschool children pooled from seven sources (10) allows the calculation of a mean storage iron 


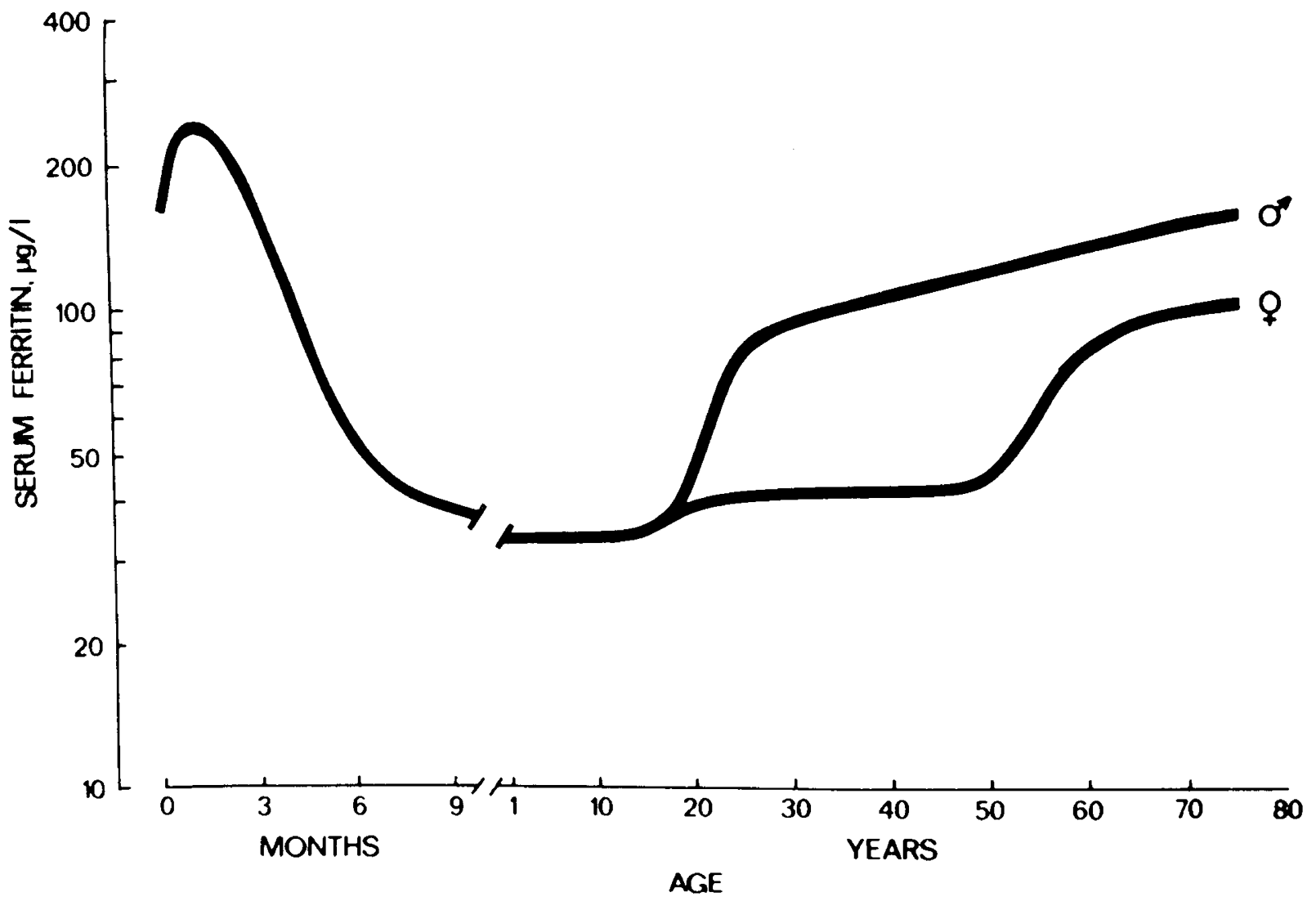

Fig. 1. Developmental changes in concentration of serum ferritin derived from the geometric means of composite figures from healthy populations (from reference 11). Reproduced with permission.

pool of $12 \mathrm{mg} / \mathrm{kg}$ if liver is assumed to contain one-third of total iron reserves (2). The average $\mathrm{SF}$ concentration in preschool children is $30 \mathrm{ng} / \mathrm{ml}$. Applying this figure in the Saarinen and Siimes equation predicts a storage iron content of $3 \mathrm{mg} / \mathrm{kg}$, quite remote from the estimates derived from published tissue data.

Furthermore, the behavior of SF concentration throughout the life-cycle has been plotted (11) (Fig. 1). The prolonged trough of SF from ages 1 through 10 years, and the overall stability of SF concentrations in relation to the expected weight-gain throughout childhood would appear to be inconsistent with the log-linear relationship between SF concentrations and body storage iron density on theoretical grounds as well.

The factorial approach to the calculation of total body iron using indirect indices of circulating and storage iron pools introduced by Saarinen and Siimes is an ingenious, inexpensive, and relatively noninvasive approach that provides a valuable basis for estimating the net biologic availability of iron from various diets. The use of the specific log-linear equation to determine storage iron density (4), however, might be acceptable for the four agegroups whose data was used to derive the equation, but it seems to predict poorly the range of iron stores expected in children aged 1-5 years. Because the factorial method is so attractive, however, we have used a more conservative and traditional estimate of the relationship between SF concentration and total iron stores $(4,5)$, and achieved estimates of iron reserves that are more harmonious with those derived from tissue measurements (12). The log-linear regression equation must be used with care, and applied only to those age-groups in which it provides estimates of storage iron that are in reasonable accord with independent determinations. The preschool child does not fall into such an age-group.

\section{APPENDIX}

The partition of total body iron in the $14-\mathrm{kg}$ child (8) was calculated assuming that the child had a hemoglobin concentra- tion of $12 \mathrm{~g} / \mathrm{dl}$ and an iron content of $3.4 \mathrm{mg} / \mathrm{g}$ of hemoglobin, and that the blood volume was $75 \mathrm{ml} / \mathrm{kg}$ of body weight.

The factorial calculation of total storage iron from data on liver concentration was based on an estimate of $100 \mu \mathrm{g}$ of iron per gram of liver wet weight (10) and assuming that the liver represented $4 \%$ of body weight with liver stores representing one-third of total iron deposits (2).

\section{REFERENCES AND NOTES}

1. Munro, H. N.: Iron absorption and nutrition. Introduction. Federation Proc., 36 2015 (1977).

2. Bothwell, T. H., and Finch, C. A.: Iron Metabolism. (Little Brown, Boston, 1962)

3. Walters, G. O., Miller, F., and Worwood, M.: Serum ferritin concentration and iron stores in normal subjects. J. Clin. Pathol., 26: 770 (1973).

4. Cook, J. D. and Finch, C. A.: Assessing iron status of a population. Am. J. Clin. Nutr., 32: 2115 (1979).

5. Cook, J. D. and Skikne, B. S.: Serum ferritin: a possible model for assessment of nutrient stores. Am. J. Clin. Nutr., 35: 1180 (1982).

6. Saarinen, U. M. and Siimes, M. A.: Iron absorption from breast milk, cow's milk, and iron-supplemented formula: an opportunistic use of changes in total body iron determined by hemoglobin, ferritin and body weight in 132 infants. Pediatr. Res., I3: 143 (1979).

7. Garry, P. J., Owen, G. M., Hooper, E. M., and Gilbert, B. A.: Iron absorption from human milk and formula with and without iron supplementation. Pediatr. Res., 15: 822 (1981).

8. Jacob, R. A., Sandstead, H. H., Klevay, L. M., and Johnson, L. K.: Utility of serum ferritin as a measure of iron deficiency in normal males undergoing repetitive phlebotomy. Blood, 56: 786 (1980).

9. Widdowson, E. M. and Dickerson, J. W. T.: Chemical composition of the body In: Mineral Metabolism: An Advanced Treatise, Comar CL, Bronner F, Eds., pp. 2-207. (Academic Press, New York, 1964).

10. Brittenham, G. M., Danish, E. H., and Harris, J. W.: Assessment of bone marrow and body iron stores: Old techniques and new technologies. Sem. Hematol., 18: 194 (1981)

11. Dallman, P. R., Siimes, M. A., and Stekel, A.: Iron deficiency in infancy and childhood. A report of the International Nutritional Anemia Consultative Group. Washington, D.C., Nutrition Foundation, 1979.

12. Caballero, B., Solomons, N. W., Batres, R., Torun, B.: Changes in total-body iron during treatment of protein-energy malnutrition: Evidence for its regulation by initial storage iron reserves. in preparation. 